\title{
Refuge
}

Canada's Journal on Refugees

revue canadienne sur les réfugiés

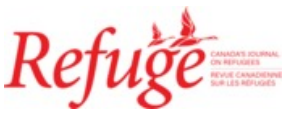

\section{Stories for Asylum: Narrative and Credibility in the United States' Political Asylum Application}

\section{Madeline Holland}

Volume 34, numéro 2, 2018

URI : https://id.erudit.org/iderudit/1055579ar

DOI : https://doi.org/10.7202/1055579ar

Aller au sommaire du numéro

Éditeur(s)

Centre for Refugee Studies, York University

ISSN

0229-5113 (imprimé)

1920-7336 (numérique)

Découvrir la revue

Citer cet article

Holland, M. (2018). Stories for Asylum: Narrative and Credibility in the United States' Political Asylum Application. Refuge, 34(2), 85-93.

https://doi.org/10.7202/1055579ar
Résumé de l'article

Cet article examine les exposés des faits exigés des demandeurs d'asile aux États-Unis. Fondé sur la participation d'universitaires des domaines de la narratologie et de la littérature, cet article soutient que la "narration d'une histoire » constitue une exigence implicite du processus de demande d'asile aux États- Unis, et que les histoires des demandeurs d'asile sont évaluées d'après leur véracité sur la base de critères conformes aux normes de véracité utilisées dans le domaine littéraire. Il examine les conséquences de l'application de normes littéraires de véracité à des histoires de demandeurs d'asile, et explore les différents cas de figure dans lesquels l'histoire " vraie » rapportée par un demandeur d'asile peut ne pas être reconnue comme telle.
Copyright (c) Refuge: Canada’s Journal on Refugees, 2018

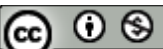

Ce document est protégé par la loi sur le droit d'auteur. L'utilisation des services d'Érudit (y compris la reproduction) est assujettie à sa politique d'utilisation que vous pouvez consulter en ligne. 


\title{
Stories for Asylum:
}

\section{Narrative and Credibility in the United States' Political Asylum Application}

\author{
MADELINE HOLLAND
}

\section{Abstract}

This article examines the narrative demands placed on asylum seekers to the United States. Engaging with scholars from the fields of narratology and literature, this article argues that "telling a story" is an implicit requirement of the asylum application process to the United States, and that the stories of asylum seekers are evaluated for their truthfulness on the basis of criteria that align with literary standards of veracity. The article examines the implications of bringing these literary standards of veracity to bear on asylum seekers' stories, and explores the ways in which a "true" story told by an asylum seeker may fail to be recognized as such.

\section{Résumé}

Cet article examine les exposés des faits exigés des demandeurs d'asile aux États-Unis. Fondé sur la participation d'universitaires des domaines de la narratologie et de la littérature, cet article soutient que la "narration d'une histoire» constitue une exigence implicite $d u$ processus de demande d'asile aux États-Unis, et que les histoires des

(C) Madeline Holland, 2018. This open-access work is licensed under a Creative Commons Attribution-NonCommercial 4.0 International Licence, which permits use, reproduction, and distribution in any medium for non-commercial purposes, provided the original authorship is credited and the original publication in Refuge: Canada's Journal on Refugees is cited. demandeurs d'asile sont évaluées d'après leur véracité sur la base de critères conformes aux normes de véracité utilisées dans le domaine littéraire. Il examine les conséquences de l'application de normes littéraires de véracité à des histoires de demandeurs d'asile, et explore les différents cas de figure dans lesquels l'histoire "vraie» rapportée par un demandeur diasile peut ne pas être reconnue comme telle.

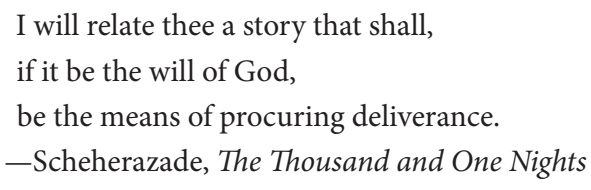

To call a story a true story is an insult to both art and truth. - Vladimir Nabokov

\section{Introduction}

became interested in the application process for political asylum in the United States during several months I spent working for a refugee resettlement agency. Many
Cette œuvre en libre accès fait lobjet d'une licence Creative Commons Attribution-NonCommercial 4.o International License, laquelle autorise l'utilisation, la reproduction et la distribution de l'œuvre sur tout support à des fins non commerciales, pourvu que l'auteur ou les auteurs originaux soient mentionnés et que la publication originale dans Refuge: revue canadienne sur les réfugiés soit citée. 
asylum seekers described the process of applying as the hardest experience of their lives, and yet also usually described the process by saying, "I had to tell them my story." I became interested in this seeming contradiction; to tell one's storywhy should that constitute the hardest experience of one's life? There is a suggestion in the phrase "tell your story" that the asylum application is an opportunity for self-expression; training materials for asylum officers stress the importance of allowing applicants to use "his or her own words" to make the claim in as "unrestricted" a manner as possible. ${ }^{1}$ But these belie the fact that not just any telling of one's story will do. The focus of my research is the application process for political asylum in the United States and the unique narrative demands it places upon applicants.

Those who have written most extensively on the process of applying for asylum have been lawyers and anthropologists, and I have drawn thoroughly on their findings. This article has drawn especially on the work of folklorist Amy Schuman and attorney Carol Bohmer, and anthropologist Marita Eastmond, who have written on the profound disconnects in understanding between American bureaucracies and the people who must navigate them. However, in contrast to these approaches, this study engages closely with the defining characteristics of narrative and of credibility in narrative, and draws on the work of scholars including Elaine Scarry and others in the field of law and literature to theorize about the tacit literary standards to which we hold asylum applicants accountable. This article argues that, rather than a colloquial approximation of what is required of asylum seekers, "telling a story" is an implicit requirement of the application process for political asylum in the United States. I argue that Western literary standards shape our understanding of what a "true story" should sound like; this conflation of literary story-telling and truthful story-telling in the context of asylum proceedings can result in the failure to recognize "true" stories told by asylum seekers.

\section{Stories for Asylum}

Today applicants for political asylum must fill out the I-589 Application for Asylum, distributed by the United States Citizenship and Immigration Services (USCIS), a division of the Department of Homeland Security (DHs). ${ }^{2}$ The instructions attached to the I-589 explicitly direct applicants that all information provided must be true: "All statements in response to questions contained in this application are declared to be true and correct under penalty of perjury." 3 Beyond this, the instructions require that an applicant must "establish that race, religion, nationality, membership in a particular social group, or political opinion was or will be at least one central reason for your persecution or why you fear persecution."4 The instructions also state, "You are strongly urged to attach additional written statements ... that support your claim. Your written statements should include events, dates, and details of your experiences that relate to your claim for asylum."5

The I-589 form itself first solicits biographical information in fill-in-the-blank boxes, before soliciting information about the applicant's arrival in the United States. Then, above a larger box, it asks:

A. Have you, your family, or close friends or colleagues ever experienced harm or mistreatment or threats in the past by anyone? If "Yes," explain in detail:

1. What happened;

2. When the harm or mistreatment or threats occurred;

3. Who caused the harm or mistreatment or threats; and

4. Why you believe the harm or mistreatment or threats occurred.

B. Do you fear harm or mistreatment if you return to your home country? If "Yes," explain in detail:

1. What harm or mistreatment you fear;

2. Who you believe would harm or mistreat you; and

3. Why you believe you would or could be harmed or mistreated. ${ }^{6}$

After filling out this form and its attachments, applicants must appear before an asylum officer or immigration judge to testify to the contents. Persuasive completion of this form, and repetition of its contents to an asylum officer or immigration judge: for asylum seekers today, this is the key that unlocks a new life, or fails to. ${ }^{7}$

It is clear upon first glance that this is a linguistic key: only through constructing something out of language can an applicant gain entrance. But just what kind of linguistic construction is it? Though official materials do not use the word story, in advocacy materials and in conversation amongst applicants, lawyers, or asylum officers, it is common enough to explain the application process for asylum as an imperative or an opportunity for the applicant to "tell her story." What is a story? How is it different from a list, a poem, a cry for help? While there is no singular consensus on the formal elements of a story, and it is still common to debate whether particular texts qualify or not, narratologists, from Aristotle to Roland Barthes to David Herman, have identified certain standard elements. ${ }^{8}$

Four characteristics reoccur in narratologists' appraisals of the necessary components of stories: (1) Stories are particular; they are built around particular entities and events, as opposed to abstract trends or general explanations. (2) Stories take place in time, recording the movements of a particular being or beings, which we call a character or characters. (3) Stories create a link between one event and the next; they have a "plot." The earliest student of narrative, 
Aristotle, explains that "of all plots ... the episodic are the worst ... in which the episodes or acts succeed one another without probable or necessary sequence."9 In other words, stories should have clear sequences, the beginning giving rise to the middle, and the middle in turn leading inexorably to the end. (4) Finally, though this criterion is slightly more flexible, most stories contain the internal, subjective component of human or human-like perceptions, of whatever or whoever is the focus of the story, as well as description of the outer world. They do not only link one event to the next, but can create a link between the inner world of characters and the outer world of events. Incorporating internal experiences of characters, stories offer a sense of, as Herman puts it, "what's it like to live through ... disruption."10 By creating "a nexus or link between the experiencing self and the world experienced," stories give a sense of how characters respond to or influence the world beyond themselves. ${ }^{11}$

The I-589 form asks applicants to describe experiences, to place those experiences in time, to give name to the persons involved, as well as assign motives to those persons. In other words, applicants are asked to create detailed cause-andeffect accounts of their lives' most disruptive experiences and integrate their internal, felt experience insofar as "fear" is concerned. These elements-(1) particularity, (2) movement through time, (3) causality or plot, and (4) felt human experience-are precisely the defining characteristics of stories. "Tell your story" is not just a colloquial approximation of what is asked of applicants in the asylum process-rather, it is an implicit requirement.

\section{How to Tell a True Story: Detailed, Plausible, Consistent}

The I-589 application demands stories; the written narrative of an applicant's experiences, usually attached to the form in an affidavit or declaration, is the "central evidence" in her case. ${ }^{12}$ There are two important caveats about stories in a legal context that differentiate them from the literary context. First, in law, storytelling functions as an argument. Second, the consequences of legal storytelling are inherently concrete. Stories told in a legal setting may follow some of conventions of stories told elsewhere but are subject to additional pressures and expectations. Paul Gewirtz, a scholar of law and literature, clarifies that "virtually everyone in the legal culture ... is explicitly or implicitly making an argument and trying to persuade. Storytelling is, or is made to function as, argument. The goal of telling stories in law is not to entertain, or to terrify, or to illuminate life, as it usually is with storytelling outside the legal culture. The goal of storytelling in law is to persuade an official decision-maker that one's story is true, to win the case, and thus to invoke the coercive force of the state on one's behalf." 13
What Gewirtz calls "the coercive force of the state," in the case of the asylum seeker, will be enacted to ensure her protection in the United States, or to order her removal and return to country she has fled.

This disproportion between the apparent insubstantiality of a story and the enormity of the decision based upon it is powerfully evoked by Scheherazade from the well-known medieval tale that frames The Thousand and One Nights. The text's King Shariyar, an unhappy ruler with an insatiable appetite for power and women, sleeps with a virgin each night and slays her in the morning. When Scheherazade is called forth for her fateful turn with the king, she devises a plan to save her life. Each night, she recites to him a story; as long as he is caught up in her tale, Shariyar spares Scheherazade's life for one more day. Scheherazade intuits that stories can be used to direct the "coercive force of the state"; asylum seekers, too, must tell stories to such an end. In an interview a U.S. asylum officer commented on what highstakes storytelling means in the asylum context: "My supervisor said, 'How are you going to feel if [the applicant] goes back and [someone] puts a bullet in his head?' And I said, 'I'm gonna feel terrible about it, obviously'. But I have to make a decision and I have to live with it. That's what this job is about. You make a decision about people's lives."14 Decisions based upon stories alter the lives of the tellers. In the case of both Scheherazade and asylum seekers, it may quite literally be the difference between life and death.

Given the critical role of an applicant's story, there is a peculiar absence of official advice on how to provide it. The I- 589 offers little formal instruction beyond the reminder that an applicant must prove his persecution was on the basis of one or more of the five protected grounds, and a strong urging to include "events, dates, and details of your experiences that relate to your claim for asylum." 15 The text recorded on the form, or attached in a written statement, known as a declaration or affidavit, may be any length or style so long as it is submitted to uscis in English. ${ }^{16}$ In the absence of detailed official guidance, advocacy groups and asylum lawyers have created a small corpus of advice on how to make this story the best, most persuasive piece of evidence. ${ }^{17}$

In her discussion of the ideal application story, Stacy Caplow, a professor of asylum law and director of the Safe Harbor Project, which offers legal representation to asylum seekers, stresses that the story must, at the very minimum, "meet the legal standard for eligibility and ... establish credibility." ${ }^{18}$ In other words, it is essential that an applicant's story (1) meet the established criteria for the definition of refugee and (2) appear to be true. Asylum lawyers agree that if an applicant does indeed meet the criteria for refugee status, her credibility-her ability to convince the asylum officer or immigration judge in writing and in person that 
what she says is true-is the determining factor of her case. Applicants must tell the truth and must tell a story; credibility is the factor that ostensibly allows them to do both. An adverse credibility finding undermines an application and is precisely what government officials are trained to listen for. As one asylum officer said when interviewed in the documentary Well-Founded Fear, in many cases "you have to just go for them in terms of their credibility, and usually you can get them. And I realize that sounds kinda sinister-you gotta get 'em-but, that's what you gotta do. It's usually not too difficult. They're not too sophisticated." ${ }^{19}$

Interestingly, many legal practitioners and literary critics agree in their assessments of what constitutes "truth" in a story. These assessments point to requirements that both complement and exceed the requirements of stories more generally. Caplow claims that for a story to be found credible by an asylum officer or an immigration judge, "the facts need to be detailed, plausible, and consistent, and the applicant must relate them convincingly in writing and orally." ${ }^{20}$ In this respect, the canons of literature and law align; these same criteria-detail, plausibility, and consistency-are acknowledged by theorists to be hallmarks of truth as defined by literary standards.

An effective asylum story, one that is credible, should be "detailed." According to Caplow, in a legal context, details are desirable because "detailed testimony seems more truthful," and furthermore, details help to "attract the reader to the individuality of [the applicant] and the particularity of his story." ${ }^{21}$ She is referring to details like times or locations that ground a story in the past, but she is also referring to other, seemingly less relevant details. Details can help "bring to life" the situation described and as a result "produce understanding, sympathy, and compassion" in a reader, she writes. ${ }^{22}$ Asylum officers reiterate that detail is necessary to convince them an applicant is telling the truth. "They have to give me detail," said one officer. "He could answer my questions. He could give me details ... if you lived it you can give me the answers." ${ }^{23}$ Another expressed his skepticism of those who did not differentiate their stories through detail. "I don't know, they're so identical," he said. "So boilerplate, there's not even anything unique about the claims, it makes you wonder." 24

Echoing Caplow's and other asylum officer's comments, critic and semiotician Roland Barthes, in his seminal essay, "The Reality Effect," claims that details that are "superfluous" to the structure or movement of a narrative, which might be discarded as "useless details," actually do the important work of making the narrative seem "real." $25 \mathrm{He}$ explains that in antiquity, picturesque or vivid description (hypotyposis) was appreciated for its beauty. Its goal was to "put things before the hearer's eyes" in a manner that was aesthetically remarkable. ${ }^{26}$ While aesthetic preference may still be in play, he claims that in modern literary realism, inclusion of detail is an attempt to create the illusion, in both historical writing and fiction, of a "pure encounter between an object and its expression," or of unmediated truth. ${ }^{27}$ Though literary critic and professor James Wood is concerned strictly with fiction, he, too, writes about the relationship between details and truth by drawing on the medieval concept of haecceitas, or "thisness." A detail with "thisness" is one that "draws abstraction towards itself and seems to kill that abstraction with a puff of palpability, any detail that centres our attention with its concretion." ${ }^{28}$ A detail with "thisness," he writes, "seems really true." 29

After "detailed," Caplow's second criterion is "plausible": could it have happened in the real world? To have certainty about the events in question, government officers, ideally, would like to see material evidence: certificates, photographs, threat notices, injuries, scars. But often, even if there is concrete evidence, applicants are not able to gather it before fleeing, or it is not conclusive. In the absence of certainty about an applicant's story, adjudicators settle for plausibility, the suggestion that what happened is reasonable and probable, that it indeed might have happened. Plausibility can be bolstered by testimonies from academics or State Department reports on human rights conditions in the country from which an applicant comes, but largely it falls to the story to satisfy.

Effective use of narrative structure helps an applicant satisfy this criterion of plausibility. Aristotle writes that stories should have "causal necessity," meaning each event is a plausible, or even necessary successor to the previous one. ${ }^{30}$ In contrast to an episodic plot, in which no event is logically linked to the previous one, a plausible plot should make clear the connection between each action and its successor. Psychologist Jerome Bruner writes that one strategy that stories can employ to establish plausibility is "narrative banalization," the production of a narrative so "socially conventional," so "in keeping with the canon" that a reader scarcely questions it. ${ }^{31}$ Asylum lawyers, in their advice to those who represent asylum seekers, draw on both causal necessity and narrative banalization as tools for asserting the plausibility of a case. Kirsten Schlenger, an asylum attorney, implicitly invokes causal necessity: "By the end of the [applicant's] declaration," she writes, "the reader should feel that there is no choice but to grant asylum." ${ }^{2}$ In other words, it should be clear that the next necessary chain in the sequence of events is the grant of asylum. Caplow, on the other hand, in her advice, draws on narrative banalization as a possible tool for making stories plausible: "The David and Goliath parable in modern terms of the brave individual struggling for freedom and democracy against a vicious tyrant is often at the heart of the claim. 
Valiant, despised groups fighting for identity and survival offer another familiar plot. Resistance to or suffering at the hands of authorities are other possible themes." 33

Asylum officers and immigration judges likely have developed expectations of how archetypal stories should end. By drawing on these "familiar" plots, an applicant bolsters the plausibility and persuasiveness of his own tale.

The last vital criterion the applicant's story must satisfy is "consistency." True stories are certainly expected to be internally consistent, but this criterion becomes a more pressing concern for an applicant when he is, inevitably, asked to repeat his story. Most applicants will tell their stories at least two times, and often three: once in writing, once in an interview, and/or once in front of a judge. For most applicants, the written version of the story is the most thorough and complete, while the interview with an asylum officer or an examination in front of an immigration judge is used to fact check, or to test the story. Dates, numbers, locations, and relationships are expected to stay the same through the multiple iterations of the claim; if they do not, an applicant will not be found credible. This premium on consistency is common across most legal proceedings. It is mimicked, like the other criteria, in standard expectations of literary narrators as well. Nonfiction writer Vivian Gornick puts it succinctly when she says, "The narrator of a non-fiction narrative must be trustworthy ... you must believe that I am really honest." 34 In narrative conventions, consistency is a foundation for trustworthiness. We believe that what is true should remain a fixed feature of a story, regardless of how many times it is told.

Caplow's last reminder about telling a credible story is that even a detailed, plausible, and consistent story ought be "[related] convincingly, in writing and orally", which is to say that it must both satisfy formal criteria and be relayed articulately. ${ }^{35}$ Scarry, in her work on human pain, forcibly points out, "To have great pain is to have certainty; to hear that another person has pain is to have doubt." ${ }^{6} 6$ She also states that a key assumption underlying anti-torture advocacy work, medicine, and law is that "verbally expressing pain is a necessary prelude to the collective task of diminishing pain." 37 Taking these together, Scarry claims (1) the more effective your language is in conveying your pain, the more effectively we are able to overcome our doubt, and (2) if you cannot tell us your pain, we cannot fix it. Below is an excerpt of a conversation between two asylum officers:

ASYLUM OFFICER 1: When I get somebody from China who I know is a $\mathrm{PhD}$, I'm much more generous with them than I am with some guy who I may think is cooking in the back of some kitchen. And it's not because-it's not-that's not how I'm thinking either. But I'm thinking that oh, this person is very articulate. Their claim is very-
ASYLUM OFFICER 2: Well of course, it makes it easier to understand it. ${ }^{38}$

The conversation suggests that asylum officers are not immune to the language in which a claim is made and may carry biases against those who are less "articulate," who relay their present fear or past suffering less effectively. In other words, asylum officers and immigration judges, like most people, are more able to believe the suffering of those who express their suffering well.

At first glance, it may seem appropriate that the appearance of truth in an asylum application resembles so closely the appearance of veracity in literature. One might imagine that true stories, regardless of the context in which they are told, tend to sound the same. I argue rather that this alignment in our legal and literary expectations is deeply problematic; though the legal system is intensely suspicious of storytellers, in the most pejorative sense of the word, the requirements of the asylum application, which so closely resemble the dictates of literary truth, blur the distinction between truth and artful storytelling.

\section{Incredible Truths}

Review your application for asylum just so that you're comfortable when you go in for your interview and you don't get nervous about your facts. Because even though it's your story sometimes under the circumstances ..

-Asylum lawyer to asylum applicant 39

Undeniably some of the stories told in asylum applications are patently not true. Such applications, ones in which any "material elements" are "deliberately fabricated" are termed "frivolous." 40 For some applicants, political asylum is an alternative to standard immigration proceedings to which they may not have access. Others who arrive in the United States without understanding the channels to legal status and no English language skills may be easy prey for "preparers" who charge them large sums of money and file applications on their behalf. These "preparers" might submit a standardized story and provide the applicant with a script to follow. ${ }^{41}$ The instructions on the I-589 form, likely in recognition of this phenomenon, state, "You may not avoid a frivolous finding simply because someone advised you to provide false information in your asylum application." 42 Others, even without "preparers," may be under the impression that they "have to furnish horror stories" in order to compete with the stories others are likely to tell. 43

But it would be too simple to suggest that most applications are either entirely true or entirely false. As one asylum officer explained, "The most skeletal application for asylum 
could have lots of great stuff and three inches of bullshit." $44 \mathrm{~A}$ 2013 article written for the New Yorker illustrated such a case: Caroline, whose family members were chased out of their homes and beaten on account of their political beliefs, told asylum officers she had been raped, convinced this was the claim more likely to win her asylum. Caroline felt she had to tell the story that she thought her asylum officer wanted to hear. According to the article, "The system demanded a certain kind of narrative if she was to be allowed to stay here, and she furnished it. She had read the expected symptoms of persecution, and repeated them upon command." 45 Some of the events in her claim were true. Others were fabricated. If this binary between the true and the false suffices to understand Caroline's case, it is too limited a system to understand all cases.

Evaluating asylum stories for their truthfulness requires a greater sensitivity to gradations of reality. Anthropologist Marita Eastmond writes, "Narratives are not transparent renditions of 'truth,' but reflect a dynamic interplay between life, experience, and story." 46 Psychologist Bruner, whose work is important to Eastmond, outlines useful distinctions for grappling with the relationship between truth and communication. There is "life as lived, the flow of events that touch on a person's life; life as experienced, how the person perceives and ascribes meaning to what happens, drawing on previous experience and cultural repertoires; and life as told, how experience is framed and articulated in a particular context to a particular audience." 47

Eastmond writes, "Put simply, narrative is a form in which activities and events are described as having a meaningful and coherent order, imposing on reality a unity which it does not inherently possess." 48 Stories usually have beginnings, middles, ends, and a clear sense of direction; "life as lived" has no such clear-cut pattern. Bruner's and Eastmond's concepts help establish that there is necessarily change, editing, shaping, and mediating in the transition from lived experience to the rendering of a story.

Given that the application process for asylum attempts to reconstruct "life as lived" from "life as told," it is necessary not only to recognize how great a gap lies between them, but also that the asylum application process's stipulations for how asylum seekers must bridge that gap are not inevitable and can even be artificial.

When asked for the story of their lives, applicants may naturally assume they may tell it the way they understand it, the way they want to tell it, rather than the way the asylum system requires it. Many applicants simply do not know what the American bureaucracy wants to hear. While the hallmarks of credibility are clear to literary scholars and legal practitioners, those metrics may be unknown and unfamiliar to applicants. Sometimes this a matter of benign over-sharing; Caplow writes that often applicants tell you things that "may be very important to them but tangential to the claim." 49 In other cases, it is a matter of different cultural norms surrounding "true stories." A young Iatmul man in New Guinea, anthropologist Eastmond writes, when asked to describe his life, began with birth and ended far in the future with his own old age; his culture did not distinguish between the facts of an individual's past and the model of what the future would someday hold. $5^{\circ}$ A Somalian applicant for asylum, cited by folklorist Shumam and attorney Bohmer, always related the story of his persecution as a group history rather than an individual one. ${ }^{51}$ Commonly applicants from countries with less focus on calendar time tell their stories on what sound to American audiences like faulty timelines. For example, one applicant explained, "In rural Kenya, you don't refer to the day by the date," but rather by the season. ${ }^{52}$ Shumam and Bohmer draw attention to the fact that individuals who are familiar with bureaucracies tend to have a more developed sense of how American officials will expect application stories to be presented. But those with no such experience are ill-prepared to put on what Shumam and Bohmer call the "cultural performance" the asylum process requires. 53

Crafting the right story out of the truth can be an arduous task for asylum seekers. Many do not recognize at first that legal representation would help them craft such a story. Others cannot afford or cannot find such representation, and the U.S. government, though granting asylum seekers the right to representation, offers no public defence or financial aid to indigent applicants. If a lawyer or volunteer does meet with an applicant for asylum to help her write a narrative, the story is usually compiled over the course of multiple interviews and many hours. In such a case, the story finally presented in the application is a combination of the applicant's voice and the lawyer's. In 2007 , applicants with legal representation were three times as likely to be granted asylum (45.6 per cent of applicants) than those without (16.3 per cent of applicants). 54 While other factors that correlate with legal representation also affect such a disparity, it is surely in large part a result of aid during the story-telling process.

Though law and literature have settled on detail, plausibility, and consistency as indicators of "truth" in stories, there is little evidence to suggest that "true" asylum stories have any of these characteristics. The demands of a credible story are in many cases profoundly incompatible with the truths of asylum seekers. Common barriers arise as applicants, aided and unaided alike, try to create stories that sound credible to the American legal system. Many of those barriers take considerable effort to overcome.

For example, research has shown that memory, especially of detail, is neither complete nor stable. People from all 
cultures, in all circumstances, are quick to forget the times, dates, frequency, duration, and sequence of the events of their lives, and the consistency of memory only deteriorates over time. ${ }^{55}$ While considerable variation in an account of the past is often overlooked in informal settings, in the asylum setting, one inconsistency in dates has been known to be the difference between acceptance and rejection. ${ }^{56}$ Preparation is useful because details can become fixed in our memory through "deliberate, repeated attention," the same kind of conscientious memorization we use to remember multiplication tables. ${ }^{57}$ One asylum officer said, "It's funny, sometimes the cases that are real, that aren't fabricated, often have more inconsistencies. You know, usually-sometimes a story that's fabricated and that's rehearsed is gonna be tighter. So that's kind of the irony of all this, you know." ${ }^{58}$

Unstable memory can speak not only to the effects of time, but also to the consequences of trauma. Asylum stories are often stories of trauma, or trauma narrowly escaped. But trauma complicates a person's ability to tell stories about the past. Dori Laub, who collected testimony from multiple Holocaust survivors, asserts that "massive trauma precludes its registration." 59 Laub suggests than any interviewer of a survivor must respect that there exists a "subtle balance between what the [survivor] knew and what she did not, or could not, know." ${ }^{\circ}$ The impulse to shy away from detail when recounting one's story, to avoid what James Wood calls details with "thisness," characterized by "concretion" and "palpability," is not always a reflection of a will to deceive; it may also be an act of self-protection, a necessary means of preventing past trauma from becoming concrete and palpable. ${ }^{61}$

Laub points out that while in some contexts, especially therapeutic ones, a listener is there to hear "what [the survivor] was there to tell," to comprehend "life as experienced," in other contexts, including the legal one, listeners take a radically different approach. ${ }^{62}$ Laub cites the example of a survivor telling the story of watching three chimneys burst into flame on the day of her release from a concentration camp. A historian comparing her account to material evidence found that only one chimney had exploded. For Laub, a psychoanalyst, the testimony authentically reflected the enormity of the occurrence in the mind of the testifier. ${ }^{63}$ The historian, or legal adjudicator for that matter, whose concern is empirical accuracy, often assumes that even one "false" claim-one that does not align with the observable historical record-discredits the validity of all claims or indicates a will to deceive. The story told by the survivor may well have been her truth and yet simultaneously discarded by an external reviewer as false. ${ }^{64}$

Applicants also experience difficulty presenting their claims in a manner that seems plausible to American audiences. By plausible I mean coherent and believable; events follow each other by "causal necessity" and fall within the realm of verisimilitude. By their very nature, in that they contain violations of human rights, asylum stories upend common assumptions of how people will or should act and thus often seem unbelievable. One lawyer, the son of Holocaust survivors and the defender of Haitian applicants for asylum, noted that for each group a "recurrent refrain" when speaking of their experiences was, "No one would ever believe this if they did not know it already to be true." 65 And indeed, both communities have been consistently met with disbelief by those far removed from the conflicts narrated, including by immigration judges. Bruner's term, "narrative banalization," the act of turning a story into one that is familiar and recognizable to its listener, may simply not be an option for those fleeing from great danger and complex political situations that they themselves may not fully understand. ${ }^{66}$

\section{Conclusion}

The Refugee Act of 1980 acknowledged that we needed greater "equity" in our treatment of asylum seekers, and while it has brought about a considerable shift in the geographic origins of asylum seekers, it has not yet lived up to its goal. Instead, it has created a system in which, for asylum seekers, a particular kind of story is the key to the door of the United States. It is a key to which the bureaucratically savvy, the well represented, and those familiar with our narrative conventions have special access, and to which the most "tempest-tost" of all may have the least access. When our notions of what a "true story" sounds like are so profoundly influenced by what a good story sounds like, as defined by literary standards, we risk conflating the two; we risk becoming confused about the distinction between a true story and a story well told, and perhaps increasingly unlikely to believe the stories of those who do not express their suffering "well." Furthermore, asylum applicants may be among the least able to produce a "true story" as the American asylum application process has defined it. Asylum seekers to the United States, eligible for asylum under the international definition, could easily speak their truth and fail to tell a "true story."

\section{Notes}

1 United States Citizenship and Immigration Service, Asylum Division, "Interviewing Part I: Overview of Nonadversarial Asylum Interview," 2006, 6.

2 All I-589 forms must be submitted in English in order to be considered eligible for review. uscis does not offer translation services.

3 United States Department of Homeland Security, U.S. Citizenship and Immigration Service, I-589, Application for Asylum and for Withholding of Removal, "Instructions," (2014) 6. 
4 United States Department of Homeland Security. U.S. Citizenship and Immigration Service. I-589, Application for Asylum and for Withholding of Removal. 2014.

5 I-589 Application for Asylum and for Withholding of Removal, 2.

6 I-589 Application for Asylum and for Withholding of Removal, 2.

7 In short, there are two basic paths to political asylum in the United States: affirmative and defensive. In an affirmative case, an applicant is already in the United States and can file an I-589 form with uscis. He will be called in for an interview with a member of the Asylum Officer Corp., an asylum officer, in a "non-adversarial" hearing. No government lawyer will argue against him; instead, the asylum officer will solicit information and decide his case. If the asylum officer grants his case, he is an "asylee." If the asylum officer denies his case, the applicant is sent to immigration court and his case is decided upon in a "defensive," "adversarial" manner, with a government lawyer arguing against him and an immigration judge deciding on his case. If the judge rules favourably, he is an asylee. If not, he is deported. If an applicant requests asylum when attempting to enter the country, he will be put straight into defensive proceedings before an immigration judge. At every point in both processes, an applicant has the right to have representation at no cost to the government. Many applicants do not have access to legal services and represent themselves. For a more thorough treatment of these policies and their multiple caveats, see Regina Germain, Asylum Primer: A Practical Guide to U.S. Asylum Law and Procedure (Washington, DC: American Immigration Lawyers Association, 2010).

8 Throughout this article, I will be using story and narrative synonymously. Some, including most famously, E.M. Forester, have made a distinction between story, a list of events without causality, and plot, which links events. In this case, I am considering stories to have plots.

9 Aristotle, Poetics, The Internet Classics Archive, http://classics.mit.edu/Aristotle/poetics.1.1.html.

10 Herman, "Introduction," The Cambridge Companion to Narrative (Cambridge: Cambridge University Press, 2007), 9.

11 Herman, "Introduction," 7.

12 Stacy Caplow, "Putting the 'I' in $\mathrm{Wr}^{\star} \mathrm{t}^{\star}$ ng: Drafting an A/ Effective Personal Statement to Tell a Winning Refugee Story," Journal of the Legal Writing Institute, 14 (2008): 249.

13 Peter Brooks and Paul D. Gewirtz, Law's Stories: Narrative and Rhetoric in the Law (New Haven, Ст: Yale University Press, 1996), 5.

14 Well-Founded Fear, Shari Robertson and Michael Camerini, dir., Epidavros Project, 2000.

15 I-589 Application for Asylum, 2.

16 An affidavit is a "voluntary declaration of facts written down and sworn to by the declarant before an officer authorized to administer oaths," which is usually a notary public. A declaration is also a written statement but is not notarized. Applicants may submit either.

17 See, for example, Caplow, "Putting the 'I' in $\mathrm{Wr}^{\star} \mathrm{t}^{\star}$ ng"; Kristen Schlenger, "The Nuts and Bolts of Representing an Asylum Claim" (PLI Corp. Law and Practice Course, Handbook Series No. 108, October 1998); or HealTorture.org for examples.

18 Caplow, "Putting the 'I' in $\mathrm{Wr}^{\star} \mathrm{t}^{\star}$ ng," 252.

19 Well-Founded Fear.

20 Caplow, "Putting the 'I' in $\mathrm{Wr}^{\star} \mathrm{t}^{\star}$ ng," 252.

21 Caplow, "Putting the 'I' in Wr*t*ng," 280.

22 Caplow, "Putting the 'I' in $\mathrm{Wr}^{\star} \mathrm{t}^{\star} \mathrm{ng}$," 280-1.

23 Well-Founded Fear.

24 Well-Founded Fear.

25 Roland Barthes, The Rustle of Language (New York: Hill and Wang, 1986), 141-2.

26 Barthes, Rustle of Language, 148

27 Barthes, Rustle of Language, 148.

28 James Wood, How Fiction Works (New York: Farrar, Straus and Giroux, 2008), 54.

29 Wood, How Fiction Works, 54.

30 Aristotle, Poetics.

31 Jerome Bruner, "The Narrative Construction of Reality," Critical Inquiry 18, no. 1 (1991): 9.

32 Schlenger, "Nuts and Bolts of Representing an Asylum Applicant," 8.

33 Caplow, "Putting the 'I' in $\mathrm{Wr}^{\star} \mathrm{t}^{\star}$ ng," 286.

34 Vivian Gornick, "The Reliable Reporter and the Untrustworthy Narrator." Soundings: An Interdisciplinary Journal 76, no. 2/3 (1993): 280.

35 Caplow, "Putting the 'I' in $\mathrm{Wr}^{\star} t^{\star}$ ng," 286.

36 Elaine Scarry, The Body in Pain: The Making and Unmaking of the World (New York: Oxford University Press, 1985), 49.

37 Scarry, Body in Pain, 9.

38 Well-Founded Fear.

39 Well-Founded Fear.

40 I-589, Application for Asylum or Withholding of Removal, 2. UsCis does not publish statistics on the number of "frivolous" findings.

41 Well-Founded Fear.

42 I-589, Application for Asylum or Withholding of Removal.

43 Suketu Mehta, "The Asylum Seeker," New Yorker, 1 August 2011, http://www.newyorker.com/magazine/2011/o8/o1/ the-asylum-seeker.

44 Well-Founded Fear

45 Mehta, "Asylum Seeker."

46 Marita Eastmond. "Stories as Lived Experience: Narratives in Forced Migration Research," Journal of Refugee Studies 20, no. 2 (2007): 249.

47 Eastmond, "Stories as Lived Experience," 249.

48 Eastmond, "Stories as Lived Experience," 250.

49 Caplow, "Putting the 'I' in $\mathrm{Wr}^{\star} \mathrm{t}^{\star}$ ng," 272.

50 Eastmond, "Narrative as Lived Experience," 252. 
51 Amy Shuman and Carol Bohmer, "Representing Trauma: Political Asylum Narrative," Journal of American Folklore 117, no. 466 (2004): 410.

52 David Ngaruri Kenney and Philip G. Schrag, Asylum Denied: A Refugee's Struggle for Safety in America (Berkeley: University of California Press, 2008), 118.

53 Shumam and Bohmer, "Representing Trauma," 410.

54 Jaya Ramji-Nogales, Andrew I. Schoenholtz, and Phillip G. Schrag, "Refugee Roulette: Disparities in Asylum Adjudication," Stanford Law Review 6o, no. 2 (2007): 341.

55 H.E. Cameron, "Refugee Status Determinations and the Limits of Memory," International Journal of Refugee Law 22, no. 4 (2010): 470.

56 Cameron, "Refugee Status Determinations," 472.

57 Cameron, "Refugee Status Determinations," 472.

58 Well-Founded Fear.

59 Shoshana Felman and Dori Laub, Testimony: Crises of Witnessing in Literature, Psychoanalysis, and History (New York: Routledge, 1991), 58.

60 Felman and Laub, Testimony, 58.

61 Wood, How Fiction Works, 9.

62 Felman and Laub, Testimony, 62-3.
63 Felman and Laub, Testimony, 63.

64 Another important component to consider with the applications of trauma survivors is that in order to be successful applicants, they must frame their story as politically motivated. Even if they understood what happened to them as a personal attack, to make their claim eligible, it must be told as part of a larger political disruption. Shumam and Bohmer claim that this is a requirement closely related to Western historical examples of dissent and persecution, and not easily comprehensible to those from other historical and political traditions.

65 Peter Margulies, "Difference and Distrust in Asylum Law: Haitian and Holocaust Refugee Narratives." Saint Thomas Law Review 6 (1993): 135.

66 Bruner, "Narrative Construction of Reality," 9.

Madeline Holland is the deputy executive director at Talent beyond Boundaries. The author may be contacted at madelineholland@post.harvard.edu. 